\title{
USE INTENSITY OF SOCIAL NETWORKS IN SOUTHERN BRAZIL
}

\author{
R.M.Wojahn ${ }^{\text {* }}$, A.L.Oliveira ${ }^{2}$, M.J.C.S.Domingues ${ }^{1}$ \\ 1 FURB - Universidade Regional de Blumenau, Brasil. \\ 2 IFC - Instituto Federal Catarinense, Brasil \\ *rafaelewojahn@gmail.com
}

Article submitted on 04/10/2017 and accepted on 08/30/2017

\begin{abstract}
A social network implies in connect people. This article aims to identify the use intensity of social network in Southern Brazil. The research was characterized by quantitative approach, descriptive, cross-sectional and survey, with a sample of 372 respondents. To data analysis was used descriptive analysis to characterize the sample, verify the access frequency of social networks
\end{abstract}

and the daily access time, and Pearson's Correlation to identify the daily access time and the social networks. The results indicated the social network used in more intensity is the Facebook and then Whatsapp, and the access occurs at home. However, all the social networks promote interactions toward users.

\section{INTENSIDADE E USO DE REDES SOCIAIS NO SUL DO BRASIL}

\section{RESUMO}

Uma rede social implica conectar pessoas. Este artigo tem como objetivo identificar a intensidade de uso da rede social no sul do Brasil. A pesquisa foi caracterizada como de abordagem quantitativa, descritiva, transversal, com uma amostra de 372 entrevistados. Para análise de dados foi utilizada a análise descritiva para caracterizar a amostra, verificar a freqüência de acesso das redes sociais e o tempo de acesso diário. E a Correlação de Pearson para identificar o tempo de acesso diário e as redes sociais. Os resultados indicaram que a rede social usada em mais intensidade é o Facebook e, em seguida, o Whatsapp, e o acesso ocorre em casa. No entanto, todas as redes sociais promovem as interações para com os usuários.

KEYWORDS: redes sociais; Facebook; Whatsapp; interação. 


\section{INTRODUCTION}

It is remarkable the Internet has revolutionized people's lives but also changed habits and patterns, introducing new forms of social interaction between individuals. With the advent of Web 2.0 new platforms for interaction and tools began to be incorporated into the daily lives of users, making people always live together in networks (MÁTTAR, 2012). Thus, in the Web 2.0, the content is determined by the user (WEIMER; GUREVYCH, 2013), promoting interaction between these (PRIMO, 2007) and engagement (SMITH; FISCHER; YONGJIAN, 2012).

A social network implies going beyond technology, promoting the interaction between users (MÁTTAR, 2012). It is understood that in a social network all connected users become content creators and sinks (MÁTTAR, 2012). Complementing, the users visit different social network with different objectives (SMITH; FISCHER; YONGJIAN, 2012).

Therefore, this article will be addressed fourteen types of social networks which enable interaction between people, and the tools Publications, Audio and Video Sharing, Video Sharing, Document Sharing, Communications, Social Networks (e.g. Facebook) Microblog, Lifestreaming, Livecast, Virtual Worlds, Social Games, MMO (Massive Multiplayer Online), and Music Forum.

The tools used by each type of social network are characterized as inductive, the most part free and offering to the users the possibility of create and sharing information (LEMOS; LÉVY, 2010). Thus, this article aims to verify the use intensity of social networks in southern Brazil.

The article is structured in six sections. The first part comprises the introduction, include the contextualization and objective of this article. The second part is the conceptual background, including concepts about social networks and each social networks used in this study. The third part corresponding the materials and the methods. The fourth part is composed to the data analysis, and, lastly, the fifth part it has the conclusion and the six, the references.

\section{CONCEPTUAL BACKGROUD}

This part comprehends the conceptual background of the study with aspects relative the social network and each social network utilized in this article.

\subsection{Social Networks}

Although there is no single concept of what is a social network, for this work, it is understood that a social network goes beyond a platform, being understood as a kind of connection between people, not the platform or the tool used to connection happens (MÁTTAR, 2012). Below there is the description of the fourteen types of social networks discussed in this article.

The tools used to Publications such as blogs allow content to be created by a user and published instantly on the web, and there may be collective construction and access to content located readers anywhere in the world (MÁTTAR, 2012). The blogs corresponding to the personal pages of an user, allows to the creator insert the information about his life, personal productions or specific content compilations too (KAPLAN; HAENLEIN, 2010). However, in generally the blogs are fed or have posts by one person, the author, and the author can allows to the others users, the readers, have interaction by the comments about the content (KAPLAN; HAENLEIN, 2010). Complementing, the blogs are common at the Web (KAPLAN; HAENLEIN, 2010).

Other tool used to publication is about Digg, used like an aggregator of notices that allow the users send links to others, like a friends, and to see the pages of other users too (LERMAN; 
GALSTYAN, 2008). The Digg comprehend the most interesting histories, considering the point of vision of the users in this social network (LERMAN; GALSTYAN, 2008).

The Audio and Video Sharing are characterized by a space to realized the upload of video and audio in a specific site, allowing getting feedback from other users through comments (MÁTTAR, 2012). In some cases is possible share the video link via other social networks. YouTube is an example of the audio and video sharing, and this platform broke with the videosharing barriers (BURGESS; GREEN, 2013). The YouTube is a popular tool of audio and video sharing and, nowadays some companies sharing advertising by this social network (SILVA, 2015).

The Image Sharing as Instagram is named as a photo sharing application and short videos, originally designed to run on mobile devices, which allows imaging and interaction with other network users (LISBOA; FREIRE, 2014). By Santos and Santos (2014) perspective, the most part of users use the Instagram to shared daily moments. To use Instagram app is necessary a smartphone or tablet (SANTOS; SANTOS, 2014). The Flickr is pointed by Silva (2015) like an interactive social network to sharing images.

The Document Sharing as Academia.edu are platforms where each user has their own profile that allows you to connect with others and share information, publications and documents via web (THELWALL; KOUSHA, 2014). On the other hand, the SlideShare, one of the platforms most commonly used for this purpose, allows presentations and videos to be shared having space for comments of other users (MÁTTAR, 2012).

The Communication tools also known as chats these are a form of synchronous interaction in which users must be connected at the same time, so there is a conversation between participants (MÁTTAR, 2012). The use of smartphones that allowed instant communication tools were popularized (ANGLANO, 2014). The e-mail is considered a form of asynchronous communication (HUMPHREYS et al., 2013).

The Social Networking are platforms that allow people to stay connected encompassing forums and other communication tools, technological sense (LISBOA; FREIRE, 2014). The most used social network is Facebook where the user creates a profile allowing sharing of photos, videos, status, events and chat with your friends on your timeline (NADKAMI; HOFMANN, 2012). At the social network is allowed send messages, invite friends and talk with others (KAPLAN; HAENLEIN, 2010).

A famous social networking is the Facebook. In this social networking the user have to create a profile to connect with others users, called friends (SMITH; FISCHER; YONGJIAN, 2012). At the Facebook is possible share contents, like texts, photos, personal interests, links in a mural, and commenting or just click in "like" in the publication of other user (SMITH; FISCHER; YONGJIAN, 2012).

Other social network is the LinkedIn, with a different objective if compared with a Facebook. The LinkedIn is a social network used with professional objective, than, is a professional network and the most part of users are men (VAN DJICK, 2013).

The Microblog is a form of communication that includes short information from a variety of other social media (HSU; LIAO, 2014) and mobility (BARNES; BÖHRINGER, 2011). Twitter is the biggest popularity of microblogging (BARNES; BÖHRINGER, 2011). The service allows users to update content as news, called "tweets" with other network users (HUMPHREYS et al., 2013), which may choose to follow him (BARNES; BÖHRINGER, 2011).

The name microblogging is derived from the number of characters allowed for postage, limited in 140 (BARNES; BÖHRINGER, 2011; HUMPHREYS et al., 2013). Are also commonly 
used as virtual diaries, in which users place their daily observations, without necessarily has a target audience for reading, but does not have the purpose for us to speak of himself (HUMPHREYS et al., 2013). In the Twitter, for example, users generally "ask for or share information, news, opinions, complaints, or details about daily activities" (SMITH; FISCHER; YONGJIAN, 2012, p. 103).

The Lifestreaming is characterized by function as an aggregator of online form of references, occurring in one place indexing all changes made in the other social media user, viewed in chronological order (MAZZOCATO, 2010). A social network considered lifestreaming is the FriendFeed. To Garg et al (2009) this platform can aggregate of many others social network, like Twitter and YouTube, for example.

The Livecast platforms as Justin.TV allow users to make their own realities shows or other programs and broadcast live via the Internet (MONTAÑO, 2014; SILVA, 2015).

The Virtual Worlds such as Second Life has a 3D interface where each user has an avatar, allowing communication and interaction with other users, in various forms of language, the sense of sound be in the environment (MÁTTAR, 2012). In this kind of social network is possible to content create (PITA, 2008). In the last years, the virtual worlds are used to educational ambient too (PITA, 2008).

The Social Games have become popular among users of social networks, with steady growth due to mobility access to such games by smartphone use (SIMÕES; REDONDO; VILAS, 2013). Games are characterized by the dynamics and operation of the choices made by the player, allowing interaction and interactivity (MÁTTAR, 2012).

The MMO (Massive Multiplayer Online Games) is an online fashion game that offers players alternative experiences or second lives (SZELL; THURNER, 2010). MMORPG (Massive Multiplayer Online Role Playing Games) is characterized by three-dimensional environments where users interact through the internet (HSU; WEN; WU, 2009). The profile of the players is varied allowing bonds of friendship, respect and gain status in the community and or fun (SZELL; THURNER, 2010) considered a digital entertainment among young people (HSU; WEN; WU, 2009).

Forums are considered asynchronous platforms where threads are created on a particular subject in order to promote a discussion whether or not moderate, with or without restriction anonymous users or insertion files (MÁTTAR, 2012).

Finally, the social networks that allow users to listen to Music like Last.fm allows to share and recommend music and radio, publications in user profile, as well as building a database of the indexed files (AMARAL, 2009).

Therefore, it becomes from the description of tools that allowed be performed from Web 2.0 to promote interaction and socialization. In this way, constituting a collective construction between network users, allowing everyone to produce and share information (PRIMO, 2007).

\section{MATERIALS AND METHODS}

This research is characterized by quantitative and descriptive approach, cross-sectional and survey. Descriptive research is used when it is desired to measure the descriptive characteristics of a research question (HAIR JR et al, 2005). This research is considered descriptive that describes and analyzes the perception of the sample on the use of social media. 
A survey quantitatively measures the perception of a sample of the population about something, and the cross-section means that the data were collected in a specific period of time (CRESWELL, 2010). For the application of the research, we used a data collection instrument with open and closed questions, divided into two blocks.

The first block was related social networks, addressing the intensity and frequency of use of social media addressed by the survey. For the intensity of assertions we used the Likert scale of 5 points, ranging from 1 "Never use" to 5 "Use every day". The frequency assertions were measured by Likert scale of 5 points, with 1 "Strongly Disagree" and 5 "Strongly Agree". On the daily use time for social media, the scale ranged from "Until 01 hours" to "More than six hours." Finally, the respondents should indicate by means of an open question, the three social media most used by them.

The second block was designed to characterize the sample of the research, addressing the gender, age group ranging from "up to 20 years" to "more than 50 years," educational level of "Elementary School" for "Graduate" , place of access of social network ranging from "at home", "at work", "mobile" and "other" and the city in which it resides.

Data collection was carried out among July 14, 2014 to September 1, 2014, through electronic form via social networks. The sample was considered as random, each individual can participate in the same (CRESWELL, 2010), with 372 respondents. The data were analyzed by SPSS Statistical Software, version 21.

For data analysis, we performed the reliability test and internal consistency of the data collection instrument through Cronbach's Alpha (CRONBACH, 1951). To meet the overall objective was conducted frequency analysis of responses to daily usage time of social network and the appointment of the three media most used by respondents.

To verify the correlation between social media and the daily use time, the Pearson correlation was performed in order to verify the association between variables (PEARSON, 1920). The correlation coefficient ranges from 0.01 to 1 , with values closer to 1 indicates a higher correlation strength (HAIR JR et al., 2005). In the fourth section is willing to data analysis.

\section{RESULTS AND DISCUSSION}

Data analysis was carried out in five stages, the first characterization of the research, using descriptive analysis, considering the percentage of frequencies obtained through the responses. The characterization of the respondents are willing in Table 01.

Table 01 - Sample

\begin{tabular}{|c|c|c|c|c|c|c|c|}
\hline \multicolumn{8}{|c|}{ Genre } \\
\hline \multicolumn{4}{|c|}{ Female: $65,5 \%$} & \multicolumn{4}{|c|}{ Male: $34,3 \%$} \\
\hline \multicolumn{8}{|c|}{ Age } \\
\hline $\begin{array}{l}\text { Up to } 20 \\
\text { years }\end{array}$ & $\begin{array}{c}21-25 \\
\text { years }\end{array}$ & $\begin{array}{c}26-30 \\
\text { years }\end{array}$ & $\begin{array}{c}31-35 \\
\text { years }\end{array}$ & $\begin{array}{c}36-40 \\
\text { years }\end{array}$ & $\begin{array}{c}41-45 \\
\text { years }\end{array}$ & $\begin{array}{c}46-50 \\
\text { years }\end{array}$ & $\begin{array}{c}\text { More } \\
\text { than } 51 \\
\text { years }\end{array}$ \\
\hline $3,8 \%$ & $18,5 \%$ & $24,2 \%$ & $25,3 \%$ & $9,7 \%$ & $5,4 \%$ & $5,9 \%$ & $7,3 \%$ \\
\hline \multicolumn{8}{|c|}{ Educational level } \\
\hline
\end{tabular}




\begin{tabular}{c|c|c|c}
\hline Elementary school & High school & Higher school & Graduate \\
\hline $2,2 \%$ & $14,8 \%$ & $39,5 \%$ & $43,5 \%$ \\
\hline \multicolumn{4}{r|}{ Place of access social network } \\
\hline Mobile & At home & At work & Others \\
\hline $26,3 \%$ & $50,8 \%$ & $22,3 \%$ & $0,5 \%$ \\
\hline
\end{tabular}

Source: Research data (2014).

Considering the sample, a predominance of female respondents $(65,5 \%)$ is observed, aged 26 - 35 years, subsequently, 26 - 30 years with a percent $24,2 \%$ and, $31-35$ years with a percent $25,3 \%$, totaling in $49,5 \%$. To educational level, predominantly Graduate $(43,5 \%)$ and accessing social network in the highest percentage $(50,8 \%)$ at home.

The second stage of analysis was realized by the Cronbach's alpha, which checks the internal consistency of the items that make up a dimension, considered more reliable the closest scores to 1 (CRONBACH, 1951). The social network dimension is composed of 14 items and had coefficient of 0,732 . The dimension to corresponding the access time has 6 assertive and Cronbach's alpha of 0,736. In this perspective, are considered reliable values above 0,7 (HAIR JR. et al., 2005), thus all the statements and dimensions were kept in the sample.

The third part of the analysis was performed by means of the frequency of use of social network in an open question in which respondents should nominate the name of the three social network most used by them. Table 02 contains the percentage of the first mentioned media for "Social Network 1" to "Social Network 2" and "Social Network 3" as well as the ranking of the five most cited media considering the total percentage, that is, the total frequency without considering the position that the media was alluded to.

Table 02 - Use frequency of social network

\begin{tabular}{c|c|c|c}
\hline \multicolumn{2}{c|}{ Social Network 1 } & \multicolumn{2}{c}{ Social Network 2 } \\
\hline Facebook & $62,4 \%$ & Facebook & $21 \%$ \\
\hline Whatsapp & $14,5 \%$ & Whatsapp & $16,7 \%$ \\
\hline E-mail & $5,6 \%$ & Instagram & $14,2 \%$ \\
\hline Others & $17,5 \%$ & Others & $48,2 \%$ \\
\hline \multicolumn{2}{c|}{ Social Network 3 } & \multicolumn{2}{|c}{ Ranking } \\
\hline Whatsapp & $12,4 \%$ & Facebook & $91,6 \%$ \\
\hline YouTube & $11,8 \%$ & Whatsapp & $43,5 \%$ \\
\hline Instagram & $9,1 \%$ & Intagram & $26,3 \%$ \\
\hline Others & $66,7 \%$ & E-mail & $22,3 \%$ \\
\hline
\end{tabular}

Source: Research data (2014).

From Table 02 it can be seen that Facebook is social network used to a greater extent by the respondents of the survey, with a percentage of $91,6 \%$ of users. Likewise, Facebook appears as social media most commonly used in "social network 1 and 2". 
The second social network with the highest percentage of users is Whatsapp is, with $43,5 \%$ considering the sample. However, Whatsapp was the only social media often enough percentage to appear as more used by the sample, the corresponding the "social network 1, 2 and 3", ranking second in the "social network 1 and 2", and the first "social network 3".

Instagram already ranks third, with a percentage of 26,3\%, according to the position "social network 2" and third for the "social network 3". YouTube is the fourth most mentioned media with a percentage of $22,3 \%$ and ranks second in the "social network 2". Finally, the E-mail is the fifth most used media (16,1\% of respondents), and ranks third in the "social network 1".

Comparing the Table 01 and the Table 02 , at the Table 01, 22,3\% of respondents used social networks at work, but when they are asked about the social network most used for them, the social network LinkedIn was not cited by the respondents.

Another question is the use of Instagram. This social network requires a smartphone or tablet to used (SANTOS; SANTOS, 2014) and according to the Table 01, 26,3\% using mobile dispositive to access the social network. The Table 02 identify the Instagram like a third social media most used by the respondents this research.

The fourth part of the analysis was performed by checking the daily use for the access to social networks. For that was used to measure the question that respondents should indicate the time for daily access to social networks. The data are displayed in Table 03.

Table 03 - Daily access to social network (per day)

\begin{tabular}{l|c}
\hline Daily access to social network (per day) & Percentage \\
\hline Up to 01 hour & $22,3 \%$ \\
\hline Of 01 hour 01 minute to 02 hours & $30,4 \%$ \\
\hline Of 02 hours 01 minute to 04 hours & $27,4 \%$ \\
\hline Of 04 hours 01 minute to 06 hours & $8,9 \%$ \\
\hline More than 06 hours o1 minute & $11 \%$ \\
\hline
\end{tabular}

Source: Research data (2014).

According to Table 03 it can be seen that the time for daily access to the prevailing social networks is 01 hour 01 minute until 2 hours each day, with a percentage of $30,2 \%$. However, according to the sample, social networks are also accessed in significant quantities up to 01 hour per day, and of 2 hours 01 minute to 4 hours per day. 19,9\% of the sample engaged more than 4 hours for access to social networks.

The fifth part of the analysis was performed using Pearson's correlation method, which indicates the degree of association between two variables (PEARSON, 1920). Therefore, it was considered social network and the time dedicated to these a day. The data are shown in Table 04, they were only considered in the media that there is a correlation, and Audio and Video Sharing, Video Sharing, Communication, Social Networking and Microblog.

Table 04 - Correlation between social network and daily access

\begin{tabular}{c|c|c|c|c|c}
\hline & $\begin{array}{c}\text { Audio and vídeo } \\
\text { sharing }\end{array}$ & Image sharing & Communication & $\begin{array}{c}\text { Social } \\
\text { Networking }\end{array}$ & Microblog \\
\hline Daily & $0,171 * *$ & $0,322^{* *}$ & $0,174 * *$ & $0,290 * *$ & $0,210^{* *}$ \\
\hline
\end{tabular}




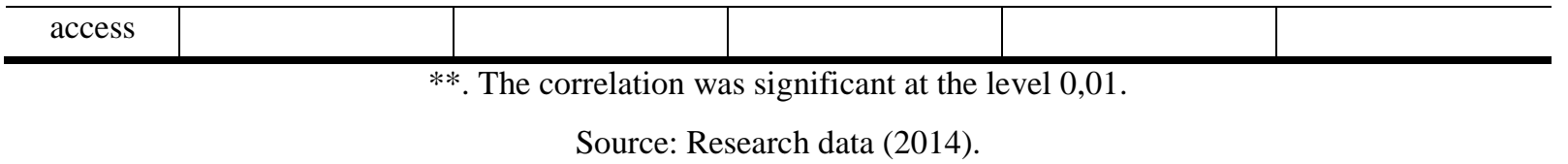

The Image Sharing is related to a greater degree with the long time use. Instagram is possible to integrate with other social networks like Facebook and Twitter, already mentioned above (LISBOA; FREIRE, 2014). Similarly, can do on Instagram imaging through a feature provided by the application, as filters to create frames and balance colors (LISBOA; FREIRE, 2014). It is evident then, the network usage time may be due to the way in which can work the image in it, in addition, the interaction with the posts of other users.

Regarding Social Networks, like Facebook is characterized by being classified by its growing popularity and number of users who connect to this network (NADKAMI; HOFMANN, 2012). It is noteworthy that in a study conducted with American users, $92 \%$ are Facebook users (HAMPTON et al., 2011). It is observed so that the popularization of network occurs in other places and not individually by a Brazilian isolated phenomenon.

The established correlation between the daily use and the Microblog, like Twitter, justified by being one of the most popular social media (HUMPHREYS et al., 2013), used for various social purposes and achieved rapid popularization (HSU; LIAO, 2014). Although there may be power of microblogging via smartphone (BARNES; BÖHRINGER, 2011).

The Communication tools such as Whatsapp are noted for being classified as instant communication and can be accessed from mobile devices such as smartphones (ANGLANO, 2014), synchronously by the users connected to the Internet (MÁTTAR, 2012). The e-mail is considered asynchronous communication, however, also involves socialization and communication between participants (KAPLAN; HAENLEIN, 2010). Although in this research the respondents point the use of social networks by home. Just $26,3 \%$ indicated that access social networks by mobile dispositive, like smartphone or tablet.

Audio and Video Sharing was correlated social network less intense with time of use of social networks. It is noteworthy that this network can upload audio and video to share (BURGESS; GREEN, 2013). However, it's also possible the user to select a particular video and hear audio only performing another activity at the same time, so finding evidence at a lower intensity of this type of social network.

\section{CONCLUSION}

In response to the general objective of this article was to verify the intensity of use of social networks in southern Brazil, the data indicated a convergence of data for certain social networks like Facebook and Whatsapp a greater percentage of use, preceded by Instagram, YouTube and Email, in view of the sample.

Similarly, when established a correlation between the use of time and existing types of social networking data indicated, in descending order, by virtue of correlation with the image sharing tools, social networking, microblogging, communication and sharing audio and video. These analyzes demonstrate a congruence between the results of the analysis, since Instagram is part of image sharing tools, Facebook characterized by a social network, Whatsapp as a form of communication, e-mail also used for this purpose and YouTube as audio and video sharing.

Although the Twitter microblog is not found between social networks most used by survey respondents possibly explain this correlation by the fact that Twitter is a tool that allows mobility, 
so it is possible that your users to interactions via smartphone, by application (BARNES; BÖHRINGER, 2011).

However, the Facebook is this social network with more use frequency and intensity by sample, demonstrates the crescent popularity of this social network. Other study realized with Americans demonstrate the same result, in other words, the diffusion of social network enter people of other place (HAMPTON et al., 2011). There are evidences that the young people prefer access to the Facebook (KAPLAN; HAENLEIN, 2010), but, on the other hand, this study demonstrate that the genre, the age, the educational level or the local access is not relevant for the use intensity for this social network, like the percentage of use in view of sample.

The others social networks like publications, documents sharing, the lifestreaming, the livecast, then virtual worlds, the social games, the MMOs, the forums and the music didn't appear with relevant results, like a frequency use or the ranking by the social network. However, must observed the time that the data was collected, because it can indicate the low popularity about these social networks in this date. Nevertheless, all social networks were scored or cited at least once as frequency or preemptive use of survey respondents.

Web 2.0 has a fundamental role in creating and propulsion of such tools, however, note that the interaction via social networks is characterized by immediacy and the intimacy, as in Whatsapp, for example (KAPLAN; HAENLEIN, 2010). However, it can also occur asynchronously, as in emails and forums.

However, it is seems that through social networks for interaction between users and the promotion of socialization. Thus, the Internet contributes to social interaction toward people localized anywhere in the world (ANGLANO, 2014). In this perspective, the Web 2.0 plays a key role in that subsequent to its advent, social networks were incorporated naturally in the daily life of its members (MÁTTAR, 2012).

The smartphones contributes to the phenomenon of communication toward people and the development the apps that allows this interaction, like Whatsapp (ANGLANO, 2014). However, in this study is not evidence the use the mobile dispositive to access social network. Thus, the respondents indicated that the access of social network occur at home, although is not specify that if access is by the mobile like smartphones or in desktop. This result can be occur because the sample configuration, it observed the educational level or the culture context of the region where occurred the data collect.

It is suggested to the future research that the reason and preferably using a specific social network are identified and the expansion of the research sample for other place and compare the results in two cultural contexts. It is also suggested that the use of social networks is analyzed together with other perspectives, such as skills or professions to verify the preference of users that have certain characteristics or specific professions.

\section{REFERENCES}

AMARAL, A. Plataforma de música online: práticas de comunicação e consumo através dos perfis. Revista Contracampo, 147 - 170, 2009.

ANGLANO, C. Forensic analysis of WhatsApp Messenger on Android smartphones. Digital Investigation, n. 11, 201 $-213,2014$.

BARNES, S. J.; BÖHRINGER, M. Modeling use continuance behavior in microblogging services: the case of Twitter. Journal of Computer Information Systems, n. 51, v. 4, 1- 10, 2011.

BURGESS, J.; GREEN, J. YouTube: online video and participatory culture. John Wiley \& Sons, 2013. 
CRESWELL, J. W. Projeto de pesquisa: métodos qualitativo, quantitativo e misto. 3. Ed. Porto Alegre: Artmed, 2010.

CRONBACH, L. J. Coefficient alpha and the internal structure of tests. Psychometrika, v. 16, n. 3, $297-334,1951$.

GARG, S. et al. Evolution of an online social aggregation network: an empirical study. In: Proceedings of the 9th ACM SIGCOMM conference on Internet measurement conference. ACM, 2009. p. 315-321.

HAIR JR, J. F. et al. Fundamentos de métodos de pesquisa em administração. Porto Alegre: Bookman, 2005.

HAMPTON, K. et al. Social networking sites and our lives. Pew Internet \& American Life Project, v. $16,2011$.

HSU, C.-L.; LIAO, Y.-C. Exploring the linkages between perceived information accessibility and microblog stickiness: the moderating role of a sense of community. Information \& Management, v. 51, n. 7, 833-844, 2014.

HSU, S. H.; WEN, M. H.; WU, M. C. Exploring user experiences as predictors of MMORPG addiction. Computers \& Education, n. 53, v. 3, 990-999, 2009.

HUMPHREYS, L., et al. Historicizing New Media: a content analysis of Twitter. Journal of Communication, v. 63, n. 3, 413-431, 2013.

KAPLAN, A. M.; HAENLEIN, M. Users of the world, unite! The challenges and opportunities of social media. Business Horizons, n. 53, $59-68,2010$.

LEMOS, A.; LÉVY, P. O futuro da internet: em direção a uma ciberdemocracia. $2^{\circ}$ edição. São Paulo: Paulus, 2010.

LERMAN, K.; GALSTYAN, A. Analysis of social voting patterns on digg. In: Proceedings of the first workshop on Online social networks. ACM, 2008. p. 7-12.

LISBOA, A.; FREIRE, G. Do instantâneo aos filtros: a estética fotográfica do Instagram. Temática, v. 10, n. 5, 2014.

MÁTTAR, J. Tutoria e interação em educação a distância. São Paulo: Cengage Learning, 2012.

MONTAÑO, S. O tempo real do Justin TV: apontamentos sobre os sentidos da transmissão ao vivo na web. XXIII Encontro Anual da Compós, Pará, 2014.

MAZZOCATO, S. B. O uso da Rede Social fragmentada como fonte de referências na prática de Lifestreaming. Em Questão, v. 15, n. 2, 2010.

NADKARNI, A.; HOFMANN, S. G. Why do people use Facebook? Personality and Individual Differences, v. 52 , $243-249,2012$.

PEARSON, K. Notes on the history of correlation. Biometrika, 25-45, 1920.

PITA, S. T. O. As interacções no Second Life: a comunicação entre avatares. Revista PRISMA. COM, n. 6, 2010.

PRIMO, A. O aspecto relacional das interações na Web 2.0. E-Compós - Revista da Associação Nacional dos Programas de Pós-Graduação em Comunicação, v. 9, 1 - 21, 2007.

SANTOS, V. L. C.; SANTOS, J. E. As redes sociais digitais e sua influência na sociedade e educação contemporâneas. HOLOS, v. 6, p. 307-328, 2014.

SIMÕES, J. REDONDO, R. D.; VILAS, A. F. A social gamification framework for a K-6 learning platform. Computers in Human Behavior, v. 29, n. 2, 345-353, 2013.

SMITH, A. N.; FISCHER, E.; YONGJIAN, C. How does brand-related user-generated content differ across YouTube, Facebook, and Twitter?. Journal of Interactive Marketing, v. 26, n. 2, p. 102-113, 2012.

SZELL, M.; THURNER, S. Measuring social dynamics in a massive multiplayer online game. Social networks, v. 32 , n. 4, 313-329, 2010.

THELWALL, M.; KOUSHA, K.. Academia. edu: social network or academic network? Journal of the Association for Information Science and Technology, v. 65, n. 4, 721-731, 2014.

VAN DIJCK, José. 'You have one identity': performing the self on Facebook and LinkedIn. Media, Culture \& Society, v. 35, n. 2, p. 199-215, 2013.

WEIMER, M.; GUREVYCH, I. Predicting the perceived quality of web forum posts. Conference on recent advances in natural language processing, 2007. 